\title{
Uncovering a connection between physiological stress and therapeutic resistance in tumor cells
}

\author{
Jason W Eng, Chelsey Reed, Kathleen M Kokolus, Rose Pitoniak, Bonnie L Hylander, Elizabeth A Repasky \\ From Society for Immunotherapy of Cancer 28th Annual Meeting \\ National Harbor, MD, USA. 8-10 November 2013
}

Environmental stress, including that caused by ambient temperature, significantly impacts many biological processes. Under conditions of cold stress, the sympathetic nervous system and a subpopulation of alternatively activated macrophages produce norepinephrine to maintain homeostasis by increasing heat production (thermogenesis). Yet in spite of these dramatic physiological effects, the impact of cold stress has been underappreciated, particularly in pre-clinical mouse models which are used extensively in basic biological research and therapy development. Namely, all animal facilities are maintained between $20-26^{\circ} \mathrm{C}$ despite the thermoneutral temperature for mice being approximately $30^{\circ} \mathrm{C}$. Therefore, mice must expend a great deal of energy to maintain body temperature at $37^{\circ} \mathrm{C}$. The full implications of this thermal stress on mouse models of disease, particularly of cancer, are unknown. In preliminary experiments, we compared the growth of tumors and their response to therapies in mice housed at $22^{\circ} \mathrm{C}$ and $30^{\circ} \mathrm{C}$. Although growth rates of human xenografts in SCID mice, a model commonly used for therapy development, were similar in these two conditions, we observed that some tumors responded differently to the same therapies. We found that MiaPaca 2 and BxPC-3 pancreatic tumor xenografts showed increased sensitivity to Apo2L/TRAIL and cisplatin when mice were placed at $30^{\circ} \mathrm{C}$ vs. $22^{\circ} \mathrm{C}$. Additionally, we saw a significant decrease in markers of M2 macrophages, a major source of norepinephrine, in the tumors of mice housed at $30^{\circ} \mathrm{C}$ compared with those at $22^{\circ} \mathrm{C}$. Thus, we hypothesize that tumor cells respond to the elevated levels of norepinephrine in cold stressed animals by increasing the expression of key survival molecules. Subsequent analysis of tumors from mice housed at $22^{\circ} \mathrm{C}$ revealed that the expression of anti-apoptotic molecules $\mathrm{Bcl}-2, \mathrm{Bcl}-\mathrm{xL}$, and $\mathrm{Mcl}-1$ were elevated compared to

Department of Immunology, Roswell Park Cancer Institute, Buffalo, NY, USA those housed at $30^{\circ} \mathrm{C}$. Furthermore, our in vitro studies show that norepinephrine can induce the expression of Bcl-2 and Bcl-xL in a time dependent manner human pancreatic tumor cell lines, and that this increased protein expression results in increased resistance to both chemotherapy and death receptor mediated apoptosis. In addition, treatment of tumor-bearing mice with the $\beta$-blocker, propranolol, increased the response of tumors in mice housed at $22^{\circ} \mathrm{C}$ to Apo2L/TRAIL, but not mice housed at $30^{\circ} \mathrm{C}$. These results support the strong possibility that the therapeutic response studied in mouse models is significantly impacted by cold stress. This study has important implications both for the development of novel therapies as well as the understanding of how temperature related stress and the activation of thermogenesis could affect drug efficacy in patients.

Published: 7 November 2013

doi:10.1186/2051-1426-1-S1-P186

Cite this article as: Eng et al:: Uncovering a connection between physiological stress and therapeutic resistance in tumor cells. Journal for ImmunoTherapy of Cancer 2013 1(Suppl 1):P186.

Submit your next manuscript to BioMed Central and take full advantage of:

- Convenient online submission

- Thorough peer review

- No space constraints or color figure charges

- Immediate publication on acceptance

- Inclusion in PubMed, CAS, Scopus and Google Scholar

- Research which is freely available for redistribution
( 2013 Eng et al; licensee BioMed Central Ltd. This is an Open Access article distributed under the terms of the Creative Commons Attribution License (http://creativecommons.org/licenses/by/2.0), which permits unrestricted use, distribution, and reproduction in any medium, provided the original work is properly cited. 